\title{
Effect of heat treatment on local structure and photocatalytic water splitting activity of $\mathrm{Ni}$-loaded $\mathrm{LiCa}_{2} \mathrm{Ta}_{3} \mathrm{O}_{10}$
}

\author{
Keita IKEUE, ${ }^{\dagger}$ Tomohiro MITSUYAMA, Keishi ARAYAMA, Akiko TSUTSUMI and Masato MACHIDA
}

Department of Nano Science and Technology, Graduate School of Science and Technology, Kumamoto University, 2-39-1 Kurokami, Kumamoto 860-8555

The photocatalytic activity of $0.5 \mathrm{wt} \%$ Ni-loaded $\mathrm{LiCa}_{2} \mathrm{Ta}_{3} \mathrm{O}_{10}$ for water splitting into a stoichiometric $\mathrm{H}_{2} / \mathrm{O}_{2}$ mixture increased about 4-fold after heat treatment at $\geq 5^{\circ} 0^{\circ} \mathrm{C}$ in a flow of $\mathrm{N}_{2}$. Local structures of the photocatalysts before and after heat treatment have been studied using XRD and XAFS. Rietveld refinement of XRD patterns revealed that the heat treatment decreased the thickness of a triple-layered perovskite slab and thus increased the distortion of octahedral $\mathrm{TaO}_{6}$ units in the both side of triple-layers. The resulting increase of dipole moment is considered to be efficient for promoting a charge separation step in the photocatalytic process. The heat treatment also converted the Ni cocatalysts from NiO/Ni core-shell to fully oxidized structure, but its effect on the photocatalytic activity was negligible.

(อ2009 The Ceramic Society of Japan. All rights reserved.

Key-words : Layered perovskite, Tantalate, Photocatalyst, Heat treatment, Water splitting

[Received August 10, 2009; Accepted October 15, 2009]

\section{Introduction}

Tantalates with perovskite-related structures show wide bandgaps $(\sim 4 \mathrm{eV})$ and high photocatalytic activities for water splitting under UV irradiation. ${ }^{1)-21)}$ A series of layered tantalates are especially of interest, because their photocatalytic activity is sensitive to the local structure of interlayer space, which can easily be modified by ion-exchange and intercalation process. In several layered oxides, such as $\mathrm{K}_{4} \mathrm{Nb}_{6} \mathrm{O}_{17}{ }^{4), 5), 11)}$ and $\mathrm{K}_{2} \mathrm{La}_{2} \mathrm{Ti}_{3} \mathrm{O}_{10}$, ${ }^{8,9)}$ which have been reported as active photocatalysts, the hydrated interlayer space is suggested to play a role of an active site. Interlayer hydration is therefore a key factor to improve the photocatalytic activity, because water molecule can easily access to the active site in the interlayer space.

We have studied that the photocatalytic activity of DionJacobson type triple-layered perovskites, $\mathrm{A}^{\prime} \mathrm{Ca}_{2} \mathrm{Ta}_{3} \mathrm{O}_{10}\left(\mathrm{~A}^{\prime}=\mathrm{Cs}\right.$, $\mathrm{Rb}, \mathrm{K}, \mathrm{Na}$ and $\mathrm{Li}),{ }^{19)}$ focusing on their hydration behavior. The interlayer space is easily hydrated only for $A^{\prime}=\mathrm{Na}$, whereas other systems $\left(\mathrm{A}^{\prime}=\mathrm{Cs}, \mathrm{Rb}, \mathrm{K}\right.$ and $\left.\mathrm{Li}\right)$ are anhydrous. The activity in the presence of $\mathrm{NiO}_{x}$ cocatalyst was strongly dependent on $\mathrm{A}^{\prime}$, increasing in the following sequence: $\mathrm{Cs}<\mathrm{Rb} \sim \mathrm{K}<\mathrm{Na}<\mathrm{Li}$. The high activity for $\mathrm{A}^{\prime}=\mathrm{Na}$ is susceptible to its hydrated interlayer. ${ }^{17)}$ This may not be consistent with the fact that $\mathrm{LiCa}_{2} \mathrm{Ta}_{3} \mathrm{O}_{10}$ shows the higher activity in spite of its anhydrous structure. However, hydrated $\mathrm{LiCa}_{2} \mathrm{Ta}_{3} \mathrm{O}_{10}$ prepared by hydrothermal treatment was found to achieve the twice higher activity than anhydrous $\mathrm{LiCa}_{2} \mathrm{Ta}_{3} \mathrm{O}_{10} .{ }^{20)}$

In the present work, we have developed another activation route of Ni-loaded $\mathrm{LiCa}_{2} \mathrm{Ta}_{3} \mathrm{O}_{10}$ by simple heat treatment. Structural characterization for $\mathrm{Ni}$ cocatalysts and $\mathrm{LiCa}_{2} \mathrm{Ta}_{3} \mathrm{O}_{10}$ was carried out using X-ray diffraction (XRD) and X-ray absorption fine structure (XAFS) technique to clarify factors controlling the photocatalytic activity.

Corresponding author: K. Ikeue; E-mail: ikeue@ chem.kumamotou.ac.jp

\section{Experimental procedure}

\subsection{Sample preparation}

A layered perovskite tantalate, $\mathrm{CsCa}_{2} \mathrm{Ta}_{3} \mathrm{O}_{10}$, was prepared by a conventional solid-state reaction of a mixture of $\mathrm{Cs}_{2} \mathrm{CO}_{3}$ (Wako Pure Chemical Industries, Ltd., 95.0\%), $\mathrm{CaCO}_{3}$ (Kishida Chemical Co., Ltd., 99.5\%) and $\mathrm{Ta}_{2} \mathrm{O}_{5}$ (Wako Pure Chemical Industries, Ltd., 99.9\%) (Cs:Ca:Ta $=1.5: 2: 3$ in molar ratio) at $1000^{\circ} \mathrm{C}$ for $10 \mathrm{~h} . \mathrm{Cs}_{2} \mathrm{CO}_{3}$ was added in $50 \mathrm{~mol} \%$ excess to compensate the loss due to its vaporization. As prepared $\mathrm{CsCa}_{2} \mathrm{Ta}_{3} \mathrm{O}_{10}$ was heated in molten $\mathrm{LiNO}_{3}$ (Wako Pure Chemical Industries, Ltd., $99.9 \%, \mathrm{Li} / \mathrm{Cs}=100$ in molar ratio) at $280^{\circ} \mathrm{C}$ for $24 \mathrm{~h}$ to obtain a $\mathrm{Li}$ form $\left(\mathrm{LiCa}_{2} \mathrm{Ta}_{3} \mathrm{O}_{10}\right)$. The exchanged compound was washed with distilled water and dried at room temperature under vacuum. Ni (0.5 wt \%) was loaded using aqueous $\mathrm{Ni}\left(\mathrm{NO}_{3}\right)_{2}$ (Wako Pure Chemical Industries, Ltd., 98.0\%) solution by an impregnation method. The Ni-impregnated compound was heated in $\mathrm{O}_{2}$ at $500^{\circ} \mathrm{C}$ for $2 \mathrm{~h}$, and submitted to reduction in $\mathrm{H}_{2}$ at $500^{\circ} \mathrm{C}$ for 2 $\mathrm{h}$ and subsequent reoxidation in $\mathrm{O}_{2}$ at $200^{\circ} \mathrm{C}$ for $2 \mathrm{~h}$. The reduction and reoxidation is to yield partially oxidized nickel cocatalyst, $\mathrm{NiO}_{x}(0.5 \mathrm{wt} \% \mathrm{Ni})$, which is efficient for photocatalytic water splitting. ${ }^{1)}$ Finally, the heat treatment of as prepared photocatalysts was carried out in a flow of $\mathrm{N}_{2}$ at $400-800^{\circ} \mathrm{C}$ for 30 $\min$.

\subsection{Characterization}

Powder X-ray diffraction (XRD) was recorded on Rigaku Co., Multiflex $(40 \mathrm{kV}, 20 \mathrm{~mA})$ with monochromated $\mathrm{Cu} \mathrm{K} \alpha$ radiation to identify crystal structure. The XRD for Rietveld analysis was measured on a Rigaku Co., RINT-2000 with monochromated $\mathrm{Cu} \mathrm{K} \alpha$ radiation $(40 \mathrm{kV}, 200 \mathrm{~mA})$ in a step-scan mode over the $2 \theta$ range of $20-80^{\circ}$ (step size, $0.02^{\circ}$, and counting time $2.4 \mathrm{~s}$ ). The structure analysis was carried out by the Rietveld method using the RIETAN-2000 profile refinement program. ${ }^{22}$ The peak shape was defined by a pseudo-Voigt function and the background level was defined by polynomial function. The scale factor, the counter zero point, the peak asymmetry, and the unit 
cell dimensions were refined in addition to the atomic parameters. A fitting between calculated and observed profiles was evaluated in term of four agreement factors, $R_{\mathrm{wp}}, R_{\mathrm{p}}, R_{\mathrm{I}}$ and $R_{\mathrm{F}}$.

Energy dispersive X-ray fluorescence analysis (XRF, Horiba Ltd., MESA-500W) was used to determine the chemical composition. Diffuse reflectance spectra were recorded with a JASCO Co. V-550 UV-vis spectrometer to determine optical band gap energy. The structure of Ni cocatalysts was observed by TEM (FEI-TECNAI F20, $200 \mathrm{kV}$ ).

Ni K-edge X-ray absorption fine structure (XAFS) spectra were recorded at BL-7C station of Photon Factory (PF), High Energy Accelerator Research Organization at Tsukuba (Proposal \#2007G613) using a Si(111) double crystal monochromator. The spectra were recorded at room temperature in a fluorescence mode using Lytle box detector filled with Ar gas. Incident X-ray was monitored by ionization chamber filled with $\mathrm{N}_{2}$ gas. A sample was pressed into a disk (diameter $10 \mathrm{~mm}$ ) after its volume was adjusted by using boron nitride powder to give an appropriate absorbance at the edge energy for the XAFS measurement. The XAFS data were processed by a REX 2000 (Rigaku Co.) program assembly. The EXAFS oscillation was extracted by fitting a cubic spline function through the post edge region. The $k^{3}$-weighted EXAFS oscillation in the $30-130 \mathrm{~nm}^{-1}$ region was Fourier-transformed. The phase shift and the backscattering amplitude were obtained from the EXAFS data of $\mathrm{NiO}$ for $\mathrm{Ni}-$ $\mathrm{O}$ and $\mathrm{Ni}-\mathrm{O}-\mathrm{Ni}$.

\subsection{Photocatalytic reaction}

Photocatalytic water splitting was carried out in an innerirradiation type quartz vessel connected to a closed gas-circulating system. A photocatalyst powder $(0.20 \mathrm{~g})$ was suspended in distilled water $(200 \mathrm{~mL})$ by a magnetic stirrer. The reaction was carried out by irradiating the mixture with a $400 \mathrm{~W}$ high-pressure $\mathrm{Hg}$ lamp. The rates of $\mathrm{H}_{2}$ and $\mathrm{O}_{2}$ evolution were determined using a gas chromatograph (Shimadzu Co., GC-8A, TCD, Ar carrier, MS-5A).

\section{Results and discussion}

\subsection{Photocatalytic property}

Table 1 shows the photocatalytic activity of $0.5 \mathrm{wt} \% \mathrm{Ni}$ loaded $\mathrm{LiCa}_{2} \mathrm{Ta}_{3} \mathrm{O}_{10}$ before and after heat treatment in a flowing $\mathrm{N}_{2}$ at different temperatures. As prepared compound exhibited steady-state evolutions of $\mathrm{H}_{2}$ and $\mathrm{O}_{2}$ with an approximately stoichiometric ratio $(2: 1)$. The rate of gas evolution was found to

Table 1. Photocatalytic Activity of $\mathrm{Ni} / \mathrm{LiCa}_{2} \mathrm{Ta}_{3} \mathrm{O}_{10}$ After Heat Treatment at Difference Temperature

\begin{tabular}{ccc}
\hline \multirow{2}{*}{ temperature ${ }^{a} /{ }^{\circ} \mathrm{C}$} & \multicolumn{2}{c}{ rate of gas evolution ${ }^{b} / \mu \mathrm{mol}^{-1}$} \\
\cline { 2 - 3 } $\mathrm{H}_{2}$ & $\mathrm{O}_{2}$ \\
\hline- & 356 & 194 \\
400 & 420 & 190 \\
500 & 1345 & 644 \\
600 & 1168 & 555 \\
700 & 877 & 414 \\
800 & 876 & 407
\end{tabular}

${ }^{a}$ The temperature for heat treatment.

${ }^{b}$ The reaction was carried out in an inner irradiation quartz cell under UV irradiation from $400 \mathrm{~W}$ high-pressure $\mathrm{Hg}$ lamp: $\mathrm{H}_{2} \mathrm{O} 200 \mathrm{~mL}$, catalyst $0.2 \mathrm{~g}$. increase with an increase of heating temperature and the maximum activity of about 4 times as high as that of untreated compound was obtained at $500^{\circ} \mathrm{C}$. The activity was decreased by further heating at higher temperatures. Because such a promoting effect could be observed by the heat treatment not only in $\mathrm{N}_{2}$ but also in air, oxygen partial pressure must not be essential. As shown in Fig. 1, enhanced photocatalytic evolutions of $\mathrm{H}_{2}$ and $\mathrm{O}_{2}$ after heat treatment at $600^{\circ} \mathrm{C}$ could be continued stably and repeated without deactivation. It should also be noted that the maximum rates of gas evolution $\left(\mathrm{H}_{2}: 1.2 \mathrm{mmol} \cdot \mathrm{h}^{-1}, \mathrm{O}_{2}: 5.6\right.$ $\mathrm{mmol} \cdot \mathrm{h}^{-1}$ ) are found to be the highest among this series of triplylayered tantalate photocatalysts including hydrothermally synthesized hydrated phases in our previous work. ${ }^{20)}$

The heat treatment in a flowing $\mathrm{N}_{2}$ was also applied to other triple-layered tantalates, $0.5 \mathrm{wt} \% \mathrm{Ni} / \mathrm{A}^{\prime} \mathrm{Ca}_{2} \mathrm{Ta}_{3} \mathrm{O}_{10}\left(\mathrm{~A}^{\prime}=\mathrm{Na}, \mathrm{K}\right.$, $\mathrm{Rb}$ and $\mathrm{Cs}$ ) as shown in Table 2 . The photocatalytic activity for $A^{\prime}=\mathrm{Na}$ remained unchanged, but the compounds with $\mathrm{A}^{\prime}=\mathrm{K}$, $\mathrm{Rb}$ and $\mathrm{Cs}$ were considerably deactivated. A significant promoting effect of heat treatment can be achieved only in the case of $\mathrm{A}^{\prime}=$ Li.

\subsection{Crystal structure of Ni-loaded $\mathrm{LiCa}_{2} \mathrm{Ta}_{3} \mathrm{O}_{10}$}

The optical band-gap energy of $\mathrm{LiCa}_{2} \mathrm{Ta}_{3} \mathrm{O}_{10}(4.2 \mathrm{eV})$ was independent of the heat treatment. To elucidate the reason for the promoting effect, the photocatalysts before and after heat treatment were characterized using XRD and XAFS, focusing on local structures of a triple-layered tantalate and a $\mathrm{Ni}$ cocatalyst. Figure 2 shows XRD patterns of $\mathrm{LiCa}_{2} \mathrm{Ta}_{3} \mathrm{O}_{10}$ and $0.5 \mathrm{wt} \% \mathrm{Ni} /$

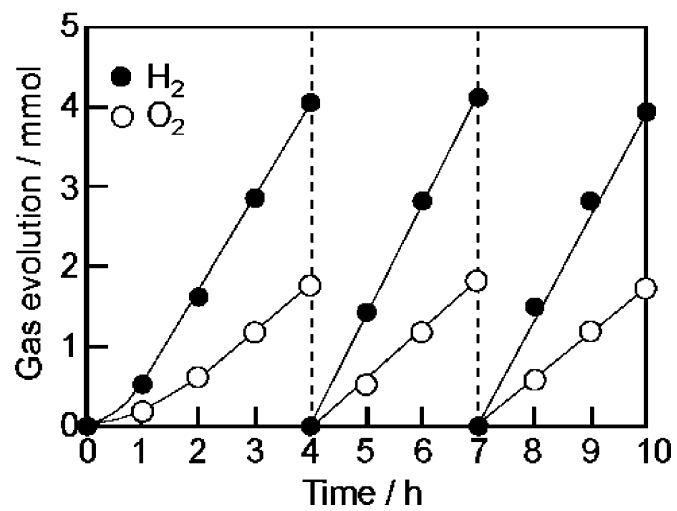

Fig. 1. Photocatalytic activity of $0.5 \mathrm{wt} \% \mathrm{Ni} / \mathrm{LiCa}_{2} \mathrm{Ta}_{3} \mathrm{O}_{10}$ after heat treatment at $600^{\circ} \mathrm{C}$. Photocatalytic reaction was conducted under the condition as shown in Table 1.

Table 2. Effect of Heat Treatment ${ }^{a}$ on the Photocatalytic Activity of $0.5 \mathrm{wt} \% \mathrm{Ni} / \mathrm{A}^{\prime} \mathrm{Ca}_{2} \mathrm{Ta}_{3} \mathrm{O}_{10}\left(\mathrm{~A}^{\prime}=\mathrm{Li}, \mathrm{Na}, \mathrm{K}, \mathrm{Rb}\right.$ and $\left.\mathrm{Cs}\right)$

\begin{tabular}{cccccc}
\hline & \multicolumn{2}{c}{$\mathrm{H}_{2}{ }^{b} / \mu \mathrm{mol} \cdot \mathrm{h}^{-1}$} & & \multicolumn{2}{c}{$\mathrm{O}_{2}{ }^{b} / \mu \mathrm{mol} \cdot \mathrm{h}^{-1}$} \\
\cline { 2 - 3 } \cline { 5 - 6 } & no treatment & heat treatment & & no treatment & heat treatment \\
\hline $\mathrm{Li}$ & 356 & 1168 & & 194 & 555 \\
$\mathrm{Na}$ & 293 & 317 & & 162 & 131 \\
$\mathrm{~K}$ & 174 & 109 & & 80 & 46 \\
$\mathrm{Rb}$ & 180 & 19 & & 91 & 6 \\
$\mathrm{Cs}$ & 89 & 23 & & 0 & 0 \\
\hline
\end{tabular}

${ }^{a}$ The samples were treated at $600^{\circ} \mathrm{C}$ in a flow of $\mathrm{N}_{2}$.

${ }^{b}$ The reaction was conducted under the conditions as described in Table 1. 


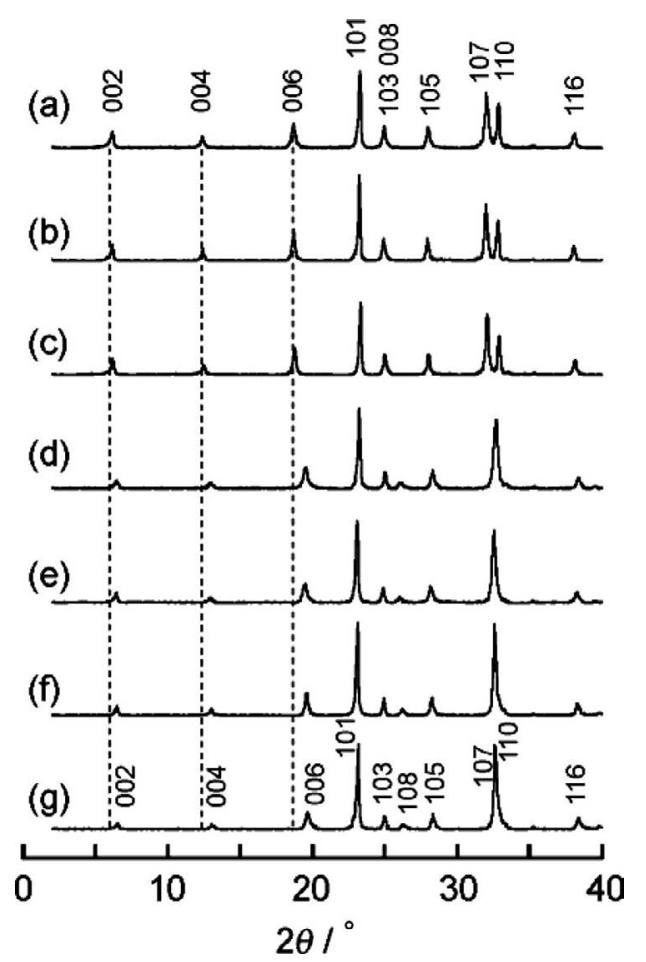

Fig. 2. $\mathrm{XRD}$ patterns of (a) as-prepared $\mathrm{LiCa}_{2} \mathrm{Ta}_{3} \mathrm{O}_{10}$, (b) $0.5 \mathrm{wt} \%$ $\mathrm{Ni} / \mathrm{LiCa}_{2} \mathrm{Ta}_{3} \mathrm{O}_{10}$, and (c) $0.5 \mathrm{wt} \% \mathrm{Ni} / \mathrm{LiCa}_{2} \mathrm{Ta}_{3} \mathrm{O}_{10}$ after heat treatment at (c) $400^{\circ} \mathrm{C}$, (d) $500^{\circ} \mathrm{C}$, (e) $600^{\circ} \mathrm{C}$, (f) $700^{\circ} \mathrm{C}$ and (g) $800^{\circ} \mathrm{C}$.

$\mathrm{LiCa}_{2} \mathrm{Ta}_{3} \mathrm{O}_{10}$ after heat treatment at $400-800^{\circ} \mathrm{C}$. The XRD pattern of $\mathrm{LiCa}_{2} \mathrm{Ta}_{3} \mathrm{O}_{10}$ was assigned to a tetragonal $I 4 / \mathrm{mmm}$ space group and remained unchanged after impregnating a Ni cocatalyst and subsequent heating at $\leq 400^{\circ} \mathrm{C}$. The peaks ascribable to $\mathrm{Ni}$ or $\mathrm{NiO}$ could not be detected because of the small amount of loading $(0.5 \mathrm{wt} \%)$. After heat treatment at $500^{\circ} \mathrm{C}$, however, a sudden shift of the $(00 l)$ peaks to higher angles occurred, suggesting a decrease of the lattice constant, $c$, in contrast to $a$. It should be noted that the photocatalytic activity increased dramatically after heating at this temperature (Table 1 ). Neither a further shift of the $(00 l)$ peaks nor an increase of the photocatalytic activity was observed by the heat treatment at higher temperatures $\left(>600^{\circ} \mathrm{C}\right)$. These results clearly suggest that the decrease in the $c$ axis length is closely associated with the enhancement of the photocatalytic activity.

Because the present $\mathrm{LiCa}_{2} \mathrm{Ta}_{3} \mathrm{O}_{10}$ compounds were totally anhydrous, the structural contraction along the $c$ axis should be associated the thickness of an interlayer or a triple-layered perovskite slab. To elucidate this point, we have carried out Rietveld analysis of XRD patterns for $\mathrm{LiCa}_{2} \mathrm{Ta}_{3} \mathrm{O}_{10}$ before and after heat treatment, both of which could be indexed with the $I 4 / \mathrm{mmm}$ space group. The Rietveld analysis for as exchanged $\mathrm{LiCa}_{2} \mathrm{Ta}_{3} \mathrm{O}_{10}$ was carried out by using the crystarographic data as an initial structural model reported by Toda et al., ${ }^{23), 24)}$ which gave agreement factors of $R_{\mathrm{wp}}=9.7 \%, R_{\mathrm{p}}=7.5 \%, R_{\mathrm{I}}=4.8 \%$ and $R_{\mathrm{F}}=3.5 \%$ with refined structural parameters. The obtained structural parameters were subsequently used as an initial structure model for refinement of $\mathrm{LiCa}_{2} \mathrm{Ta}_{3} \mathrm{O}_{10}$ after heat treatment at $600^{\circ} \mathrm{C}$. The observed, calculated and difference diffraction profiles are shown in Fig. 3. The isotropic atomic displacement parameter was fixed at $0.001 \mathrm{~nm}^{2}$ which was reported for $\mathrm{LiCa}_{2} \mathrm{Ta}_{3} \mathrm{O}_{10}$ by Toda et al. ${ }^{24)}$ The calculated profiles were in good agreement with the observed diffraction profile and gave

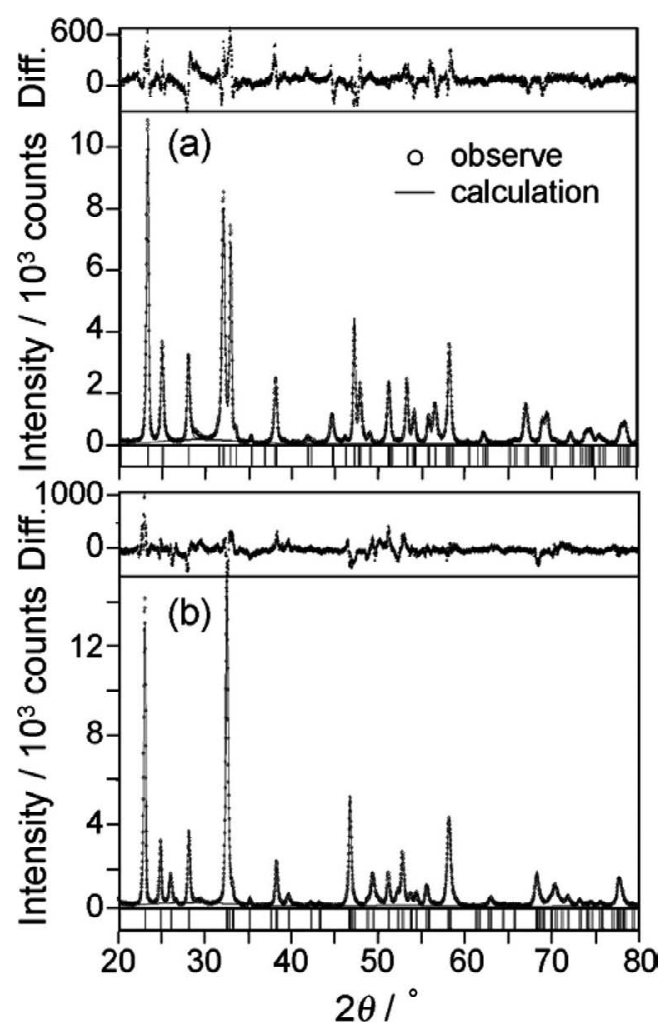

Fig. 3. Rietveld X-ray powder diffraction pattern fitting for $\mathrm{LiCa}_{2} \mathrm{Ta}_{3} \mathrm{O}_{10}$ (a) before and (b) after heat treatment at $600^{\circ} \mathrm{C}$. The difference between the calculated and observed patterns is shown on the top. The bottom bands display bragg reflections.

agreement factors of $R_{\mathrm{wp}}=9.2 \%, R_{\mathrm{p}}=7.0 \%, R_{\mathrm{I}}=5.6 \%$ and $R_{\mathrm{F}}=$ $3.8 \%$. Table 3 summarizes the refined structural parameters. The $\mathrm{Ta}-\mathrm{O}$ lengths and $\mathrm{O} 2-\mathrm{Ta}-\mathrm{O} 3$ angles calculated from refined parameters are illustrated as a structure model in Fig. 4.

As shown in Table 3, the heat treatment decreases the lattice constant, $c$, by $0.11 \mathrm{~nm}$, which results from the thickness of a triple-layered perovskite slab decreasing by $0.055 \mathrm{~nm}$. The thickness of the slab is the sum of doubled lengths of $\mathrm{Ta}(1)-\mathrm{O}(2)$ and $\mathrm{O}(2)-\mathrm{Ta}(2)-\mathrm{O}(4)$ (Fig. 4), but the latter bond was found to be shortened significantly. In recent studies on the structural refinement of layered niobate perovskites, ${ }^{25), 26)}$ the crystal structure with $\mathrm{NbO}_{6}$ octahedron tilting from the $c$ axis has been reported, which may affect the thickness of a perovskite slab. However, the layered tantalate perovskites with tilting $\mathrm{TaO}_{6}$ octahedron have not been reported. In contrast to the almost symmetric $\mathrm{Ta}(1) \mathrm{O}_{6}$ octahedron in the center, $\mathrm{Ta}(2) \mathrm{O}_{6}$ octahedron in both side of the triple layer are highly distorted to yield a dipole moment. The dipole moments of $\mathrm{Ta}(2) \mathrm{O}_{6}$ octahedron were calculated as 12.8 $\mathrm{D}$ and 14.2 $\mathrm{D}$ for the compound before and after the heat treatment, respectively. According to the series of studies reported by Inoue et al., ${ }^{27), 28)}$ the photocatalytic activity of perovskite-related oxides is correlated with the dipole moment of a metal-oxygen polyhedron. The dipole moments generated by the distortion of an octahedron lead to a local electric field useful for the electronhole separation upon photoexcitation.

In our previous report, ${ }^{19)}$ the electronic structure of $\mathrm{RbCa}_{2} \mathrm{Ta}_{3} \mathrm{O}_{10}$ was studied by the first-principle calculation using the FLAPW method. Judging from total and partial DOS of four oxygen sites, $\mathrm{O}(1)-\mathrm{O}(4)$, the terminal oxygen, $\mathrm{O}(4)$, which faces to the interlayer, contributes mostly to the valence band top. This 
Table 3. Crystallographic Data of $\mathrm{LiCa}_{2} \mathrm{Ta}_{3} \mathrm{O}_{10}$ Before and After Heat Treatment at $600^{\circ} \mathrm{C}$

\begin{tabular}{lccccclc}
\hline & atom & site $^{a}$ & $g^{b}$ & $x$ & $y$ & \multicolumn{1}{c}{$z$} & $\mathrm{~B} / \mathrm{nm}^{2}$ \\
\hline \multicolumn{7}{c}{$\mathrm{LiCa}_{2} \mathrm{Ta}_{3} \mathrm{O}_{10}$} \\
$I 4 / m m m$ (No. 139) & $\mathrm{Li}$ & $4 \mathrm{~d}$ & 0.5 & 0.0 & 0.5 & 0.2500 & 0.001 \\
$a=0.38500(7) \mathrm{nm}$ & $\mathrm{Ca}$ & $4 \mathrm{e}$ & 1.0 & 0.0 & 0.0 & $0.4234(3)$ & 0.001 \\
$c=2.8374(1) \mathrm{nm}$ & $\mathrm{Ta} 1$ & $2 \mathrm{a}$ & 1.0 & 0.0 & 0.0 & 0.0000 & 0.001 \\
$R_{\mathrm{wp}}=9.72 \%$ & $\mathrm{Ta} 2$ & $4 \mathrm{e}$ & 1.0 & 0.0 & 0.0 & $0.1495(0)$ & 0.001 \\
$R_{\mathrm{p}}=7.51 \%$ & $\mathrm{O} 1$ & $4 \mathrm{c}$ & 1.0 & 0.0 & 0.5 & 0.0000 & 0.001 \\
$R_{\mathrm{I}}=4.77 \%$ & $\mathrm{O} 2$ & $4 \mathrm{e}$ & 1.0 & 0.0 & 0.0 & $0.0718(8)$ & 0.001 \\
$R_{\mathrm{F}}=3.48 \%$ & $\mathrm{O} 3$ & $8 \mathrm{~g}$ & 1.0 & 0.0 & 0.5 & $0.1302(6)$ & 0.001 \\
& $\mathrm{O} 4$ & $4 \mathrm{e}$ & 1.0 & 0.0 & 0.0 & $0.2105(0)$ & 0.001 \\
& & & & & & & \\
$I 4 / m m m(\mathrm{No} .139)$ & $\mathrm{Li}$ & $4 \mathrm{~d}$ & 0.5 & 0.0 & 0.5 & 0.2500 & 0.001 \\
$a=0.38833(1) \mathrm{nm}$ & $\mathrm{Ca}$ & $4 \mathrm{e}$ & 1.0 & 0.0 & 0.0 & $0.4184(3)$ & 0.001 \\
$c=2.7256(2) \mathrm{nm}$ & $\mathrm{Ta} 1$ & $2 \mathrm{a}$ & 1.0 & 0.0 & 0.0 & 0.0000 & 0.001 \\
$R_{\mathrm{wp}}=9.23 \%$ & $\mathrm{Ta} 2$ & $4 \mathrm{e}$ & 1.0 & 0.0 & 0.0 & $0.1491(1)$ & 0.001 \\
$R_{\mathrm{p}}=6.98 \%$ & $\mathrm{O} 1$ & $4 \mathrm{c}$ & 1.0 & 0.0 & 0.5 & 0.0000 & 0.001 \\
$R_{\mathrm{I}}=5.60 \%$ & $\mathrm{O} 2$ & $4 \mathrm{e}$ & 1.0 & 0.0 & 0.0 & $0.0779(7)$ & 0.001 \\
$R_{\mathrm{F}}=3.75 \%$ & $\mathrm{O} 3$ & $8 \mathrm{~g}$ & 1.0 & 0.0 & 0.5 & $0.1246(6)$ & 0.001 \\
& $\mathrm{O} 4$ & $4 \mathrm{e}$ & 1.0 & 0.0 & 0.0 & $0.2091(1)$ & 0.001 \\
\hline
\end{tabular}

${ }^{a}$ Multiplicity and Wyckoff nonation

${ }^{b}$ Occupancy

(a)

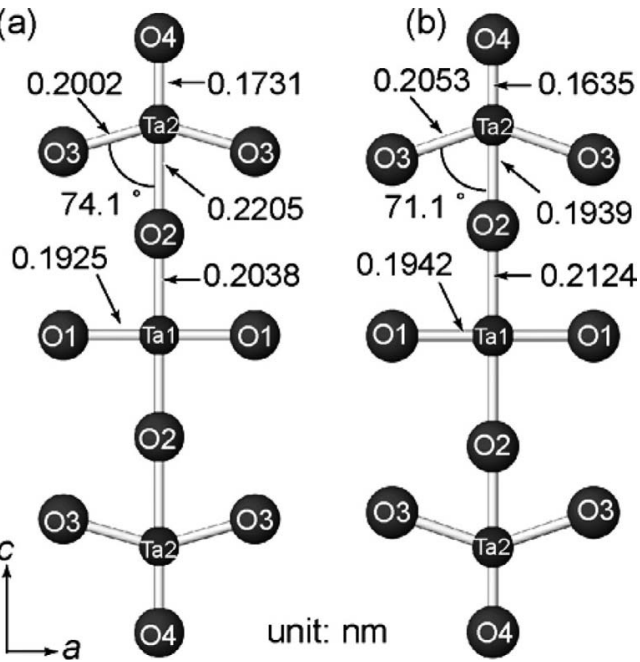

Fig. 4. Crystal structure of $\mathrm{LiCa}_{2} \mathrm{Ta}_{3} \mathrm{O}_{10}$ (a) before and (b) after heat treatment.

is indicative of preferential distribution of holes generated under photoirradiation. By contrast, photogenerated electrons are accommodated in the conduction band consisting mainly of $\mathrm{Ta}$ $\mathrm{d}$ bands running along the $a b$ plane. The increase in dipole moment of $\mathrm{Ta}(2) \mathrm{O}_{6}$ octahedron would cause a positive effect on such a charge separation process. Moreover, the mobility of electrons and holes along the $c$ axis may be improved by the enhancement of hybridization between $\mathrm{Ta}(2)$ and $\mathrm{O}(2) / \mathrm{O}(4)$ orbitals due to decreased $\mathrm{Ta}(2)-\mathrm{O}$ distances. These modifications of the electronic structure of thinner triple-layers are considered

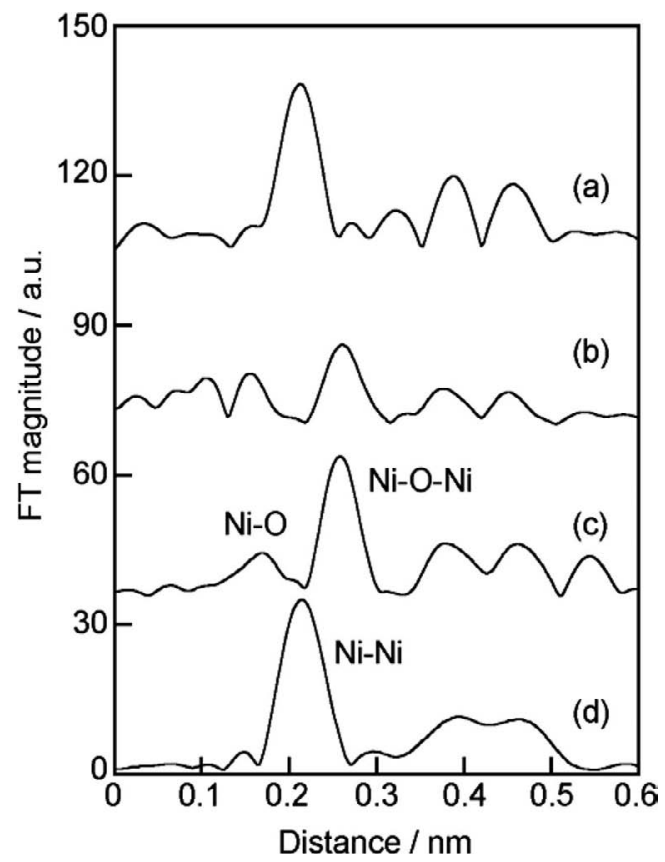

Fig. 5. Fourier transforms of $k^{3}$-weighted Ni K-edge EXAFS of (a) 0.5 wt $\% \mathrm{Ni} / \mathrm{LiCa}_{2} \mathrm{Ta}_{3} \mathrm{O}_{10}$, (b) $0.5 \mathrm{wt} \% \mathrm{Ni} / \mathrm{LiCa}_{2} \mathrm{Ta}_{3} \mathrm{O}_{10}$ after heat treatment at $600^{\circ} \mathrm{C}$, (c) $\mathrm{NiO}$ and (d) $\mathrm{Ni}$ foil.

Table 4. Structural Parameters Obtained from a Curve-fitting Analysis $^{a}$ of Ni K-egde EXAFS for $\mathrm{Ni} / \mathrm{LiCa}_{2} \mathrm{Ta}_{3} \mathrm{O}_{10}$ Before and After Heat Treatment

\begin{tabular}{llrcc}
\hline \multicolumn{1}{c}{ sample } & shell & $\begin{array}{c}\mathrm{CN}^{b} \\
( \pm 0.2)\end{array}$ & $\begin{array}{c}r^{c} / \mathrm{nm} \\
( \pm 0.003)\end{array}$ & $\begin{array}{c}\sigma^{2 d} / 10^{-4} \mathrm{~nm}^{2} \\
( \pm 0.02)\end{array}$ \\
\hline $\mathrm{Ni} / \mathrm{LiCa}_{2} \mathrm{Ta}_{3} \mathrm{O}_{10}$ & $\mathrm{Ni}-\mathrm{Ni}$ & 10.1 & 0.249 & 0.41 \\
$\mathrm{Ni} / \mathrm{LiCa}_{2} \mathrm{Ta}_{3} \mathrm{O}_{10}(600)^{e}$ & $\mathrm{Ni}-\mathrm{O}$ & 5.4 & 0.203 & 0.28 \\
& $\mathrm{Ni}-\mathrm{O}-\mathrm{Ni}$ & 6.7 & 0.299 & 0.46 \\
$\mathrm{Ni}$ foil & $\mathrm{Ni}-\mathrm{Ni}$ & 12.0 & 0.250 & 0.41 \\
$\mathrm{NiO}$ & $\mathrm{Ni}-\mathrm{O}$ & 6.0 & 0.210 & 0.28 \\
& $\mathrm{Ni}-\mathrm{O}-\mathrm{Ni}$ & 12.0 & 0.297 & 0.46 \\
\hline
\end{tabular}

${ }^{a}$ Interval of $k$-space to $r$-space of FT is $30-130 \mathrm{~nm}^{-1}$.

${ }^{b}$ Coordination number.

${ }^{c}$ Atomic distance.

${ }^{d}$ Debye-Waller factor.

${ }^{e}$ After heat treatment at $600^{\circ} \mathrm{C}$.

as possible reasons for the enhanced photocatalytic activity of $\mathrm{Ni} / \mathrm{LiCa}_{2} \mathrm{Ta}_{3} \mathrm{O}_{10}$ upon heating at $\geq 500^{\circ} \mathrm{C}$.

\subsection{Local structure of $\mathrm{Ni}$ cocatalyst}

Because a low-loading Ni cocatalyst could not be detected by $\mathrm{XRD}$, the structure was investigated by Ni K-edge EXAFS. Figure 5 shows Fourier transforms of $k^{3}$-weighted $\mathrm{Ni}$ K-edge EXAFS of $0.5 \mathrm{wt} \% \mathrm{Ni} / \mathrm{LiCa}_{2} \mathrm{Ta}_{3} \mathrm{O}_{10}$ before and after heat treatment at $600^{\circ} \mathrm{C}$ in comparison with two references, $\mathrm{NiO}$ and $\mathrm{Ni}$ foil. All data are presented without corrections for phase shifts. The observed peaks are shifted to lower $r$-value from true atomic distances. The structural parameters obtained from a curve-fitting analysis are listed in Table 4. The atomic distance $(r=0.249 \mathrm{~nm})$ of first coordination shell for as prepared $\mathrm{Ni} / \mathrm{LiCa}_{2} \mathrm{Ta}_{3} \mathrm{O}_{10}$ agreed with the $\mathrm{Ni}-\mathrm{Ni}$ atomic distance of $\mathrm{Ni}$ metal. After heat treatment 


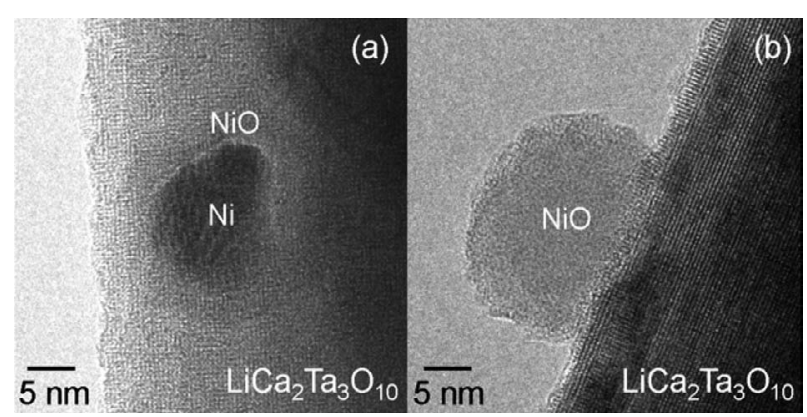

Fig. 6. TEM photographs of $0.5 \mathrm{wt} \% \mathrm{Ni} / \mathrm{LiCa}_{2} \mathrm{Ta}_{3} \mathrm{O}_{10}$. (a) Heat treatment at $600^{\circ} \mathrm{C}$ before $\mathrm{Ni}$ loading, (b) heat treatment at $600^{\circ} \mathrm{C}$ after $\mathrm{Ni}$ loading.

at $600^{\circ} \mathrm{C}$, the $\mathrm{Ni}-\mathrm{Ni}$ shell peak at $0.249 \mathrm{~nm}$ disappeared, the first and second shell peaks corresponding to $\mathrm{Ni}-\mathrm{O}$ and $\mathrm{Ni}-\mathrm{O}-\mathrm{Ni}$ were observed at 0.205 and $0.299 \mathrm{~nm}$, respectively. The atomic distance of $\mathrm{Ni}-\mathrm{O}$ after the heat treatment was $0.007 \mathrm{~nm}$ shorter than that of $\mathrm{NiO}$. Nevertheless, the coordination number of nearest neighboring oxygen was 5.4 , which was almost same with that of $\mathrm{NiO}$. These results indicate the change of local structure of Ni cocatalyst from metallic to fully oxidized state after heat treatment.

It is well-known that partially oxidized $\mathrm{Ni}$ cocatalyst, $\mathrm{NiO}_{x}$ having $\mathrm{NiO} / \mathrm{Ni}$ metal core-shell structure is mostly efficient for photocatalytic water splitting. ${ }^{1)}$ Therefore, the effect of full oxidation of $\mathrm{Ni}$ on the photocatalytic activity of the present system was studied. The heat treatment was applied to $\mathrm{LiCa}_{2} \mathrm{Ta}_{3} \mathrm{O}_{10}$ before and after loading $\mathrm{Ni}$ to compare the cocatalyst having fully oxidized and $\mathrm{NiO} / \mathrm{Ni}$ core-shell structure. As shown in TEM photographs (Fig. 6), Ni cocatalysts in both photocatalysts were highly dispersed on the surface of $\mathrm{LiCa}_{2} \mathrm{Ta}_{3} \mathrm{O}_{10}$ as hemispherical particles with the similar size of about 20 nanometers, but their local structure was quite different. When the heat treatment was applied before $\mathrm{Ni}$ loading (a), a $\mathrm{NiO}$ shell of $2 \mathrm{~nm}$ thick around a $\mathrm{Ni}$ core was formed. By contrast, the heat treatment applied after Ni loading as above described (b), metallic Ni cores seemed to be fully oxidized to form a $\mathrm{NiO}$ particle with an amorphous structure. The rates of gas evolution by water splitting over each photocatalysts were; Fig. $6(\mathrm{a}), \mathrm{H}_{2}: 1.39 \mathrm{mmol} \cdot \mathrm{h}^{-1}$ and $\mathrm{O}_{2}: 0.65 \mathrm{mmol} \cdot \mathrm{h}^{-1}$ and Fig. $6(\mathrm{~b}), \mathrm{H}_{2}: 1.35 \mathrm{mmol} \cdot \mathrm{h}^{-1}$ and $\mathrm{O}_{2}$ : $0.64 \mathrm{mmol} \cdot \mathrm{h}^{-1}$. It should be noted that the observed rates of gas evolution in photocatalytic water splitting were almost the same. Consequently, we concluded the local structure of Ni cocatalyst should not be essential for the photocatalytic activity of the present system.

\section{Conclusions}

The present study has found for the first time that photocatalytic activity of $\mathrm{Ni} / \mathrm{LiCa}_{2} \mathrm{Ta}_{3} \mathrm{O}_{10}$ for the water splitting increases about 4 -fold by simple heat treatment at $\geq 500^{\circ} \mathrm{C}$. The Rietveld analysis of XRD patterns suggested that the activation was associated with the structural change of metastable $\mathrm{LiCa}_{2} \mathrm{Ta}_{3} \mathrm{O}_{10}$ phase. This is largely due to the decrease of thickness of a triplelayered perovskite slab as a result of the distortion of $\mathrm{Ta}(2) \mathrm{O}_{6}$ octahedra. The resultant increase in the dipole moment is beneficial for the separation of photo-generated hole/electron pairs and thus total photocatalytic efficiency. The heat treatment also converted the local structure of $\mathrm{Ni}$ cocatalysts from $\mathrm{NiO} / \mathrm{Ni}$ coreshell nanoparticles to fully oxidized $\mathrm{NiO}$ nanoparticles. However, the effect on the photocatalytic water splitting is negligible.

Acknowledgements Part of this work was financially supported by Core Research for Evolutional Science and Technology (CREST).

\section{References}

1) K. Domen, S. Naito, M. Soma, T. Ohnishi and K. Tamaru, $J$. Chem. Soc. Chem. Commun., 543-544 (1980).

2) K. Domen, S. Naito, T. Ohnishi and K. Tamaru, Chem. Phys. Lett., 92, 433-434 (1982).

3) K. Domen, A. Kudo and T. Ohnishi, J. Catal., 102, 92-98 (1986).

4) A. Kudo, A. Tanaka, K. Domen, K. Maruya, K. Aika and T. Ohnishi, J. Catal., 111, 67-76 (1988).

5) A. Kudo, K. Sayama, A. Tanaka, K. Asakura, K. Domen, K. Maruya and T. Onishi, J. Catal., 120, 337-352 (1989).

6) Y. Inoue, T. Kubokawa and K. Sato, Chem. Commun., 12981299 (1990).

7) Y. Inoue, T. Niiyama, Y. Asai and Y. Sato, Chem. Commun., 579-580 (1992).

8) T. Takata, K. Shinohara, A. Tanaka, M. Hara, J. N. Kondo and K. Domen, J. Photochem. Photobiol., 106, 45-49 (1997).

9) T. Takata, Y. Furumi, K. Shinohara, A. Tanaka, M. Hara, J. N. Kondo and K. Domen, Chem. Mater., 9, 1063-1064 (1997).

10) A. Kudo and H. Kato, Chem. Lett., 867-868 (1997).

11) K. Sayama, A. Tanaka, K. Domen, K. Maruya and T. Onishi, J. Photochem. Photobiol. A: Chem., 114, 125-135 (1998).

12) T. Ishihara, H. Nishiguchi, K. Fukamachi and T. Takita, $J$. Phys. Chem. B, 103, 1-3 (1999).

13) M. Machida, J. Yabunaka and T. Kijima, Chem. Commun., 1939-1940 (1999).

14) A. Kudo, H. Kato and S. Nakagawa, J. Phys. Chem. B, 104 , 571-575 (2000).

15) M. Machida, J. Yabunaka and T. Kijima, Mater. Chem., 12, 812-817 (2000).

16) H. Kato and A. Kudo, J. Phys. Chem. B, 105, 4285-4292 (2001).

17) C. T. K. Thaminimulla, T. Takata, M. Hara, J. N. Kondo and K. Domen, J. Catal., 196, 362-365 (2001).

18) H. Kato, K. Asakura and A. Kudo, J. Am, Chem. Soc., 126, 3082-3089 (2003).

19) M. Machida, T. Mitsuyama, K. Ikeue, S. Matsushima and M. Arai, J. Phys. Chem. B, 109, 7801-7806 (2005).

20) T. Mitsuyama, A. Tsutsumi, T. Hata, K. Ikeue and M. Machida, Bull. Chem. Soc. Japan, 81, 401-406 (2008).

21) T. Mitsuyama, A. Tsutsumi, S. Sato, K. Ikeue and M. Machida, J. Solid State Chem., 181, 1419-1424 (2008).

22) F. Izumi and T. Ikeda, Mater. Sci. Forum, 321, 198-205 (2000).

23) K. Toda, T. Teranishi, Z. G. Ye, M. Sato and Y. Hinatsu, Mater. Res. Bull., 34, 971-982 (1999).

24) K. Toda and M. Sato, J. Mater. Chem., 6, 1067-1071 (1996).

25) W. T. Fu and D. J. W. IJdo, J. Solid State Chem., 179, 10221028 (2006).

26) T. Tokumitsu, K. Toda, T. Aoyagi, D. Sakuraba, K. Uematsu and M. Sato, J. Ceram. Soc. Japan, 114, 795-797 (2006).

27) J. Sato, S. Saito, H. Nishiyama and Y. Inoue, J. Photochem. Photobiol. A: Chem., 148, 85-89 (2002).

28) J. Sato, H. Kobayashi and Y. Inoue, J. Phys. Chem. B, 107, 7970-7975 (2003). 